\title{
Flow rate variation and biological agents that obstruct drippers of swine effluent
}

\author{
Rafael Oliveira Batista ${ }^{*}$, Rubens Alves de Oliveira², Maria Elidayane da Cunha', \\ Rutilene Rodrigues da Cunha', Jeane Cruz Portela', Marcelo Tavares Gurgel'
}

Federal Rural University of Semi-Árido, Brazi

2Federa University of Viçosa, Brazil

*Corresponding author, e-mail: rafaelbatista@ufersa.edu.br

\begin{abstract}
Emitter clogging is the major problem of drip irrigation systems operating with wastewater. The objective of this study was to evaluate the alteration of the flow rate variation coefficient (FVC) and to identify the biological agents that cause obstruction in drip units operating with swine effluent and public water supply. The experiment was set up in a split-plot scheme, with the times of application of swine effluent and public water supply in the main plots and dripper types in the secondary parcels, evaluating times of FVC in the tertiary parcels, using a completely randomized design (CRD) with three repetitions. The FVC of the drip subunits was calculated on every 40 hours as well as the microscopic analysis of the biological agents of clogging, until $160 \mathrm{~h}$. At the end of the tests, biofilm samples were collected in each drip unit to identify the groups of predominant bacteria. The results indicated that the FVC was effective in detecting the clogging of the emitters, evidencing that the construction characteristics and the times of application of swine effluent and of the public water supply interfere in this process. Microscopic analyzes of the biofilm indicated that the main biological agents that caused obstruction were algae, bacteria, fungi and protozoa.
\end{abstract}

Keywords: algae, bacteria, clogging, water reuse

\section{Introduction}

The water scarcity and pollution problems increase worldwide, indicating that the use of wastewater for irrigation purposes minimizes the current imbalance between supply and demand for public water supply (Puig-Bargués et al., 2010; Song et al., 2017).

In this context, emitters clogging has become one of the main obstacles of drip irrigation in the application of effluents. Several studies with wastewater types have shown that drip obstruction affects both the useful life and the hydraulic performance of the application systems (Liu \& Huang, 2009; Eroglu et al., 2012; Li et al., 2012; Batista et al., 2013; Silva et al., 2013;
Batista ef al., 2014; Oliver ef al., 2014; Batista ef al., 2016; Marques et al., 2016; Zhou et al., 2016; Batista et al., 2018).

In the wastewater it is possible to find several types of biological agents that can lead to drip obstruction, such as bacteria and fungi (Şahin et al., 2005; Dazhuang et al., 2009), algae (Batista et al., 2009; Batista et al., 2015), protozoa and worms (Mesquita et al., 2016a, b).

The drippers obstruction lead to lower flow rate (Batista et al., 2014; Fernandes et al., 2014) and uneven application of the effluent (Yan et al., 2010; Batista et al., 2013; Batista et al., 2018) in drip irrigation systems.

In order to detect the clogging of the 
emitters, there are several indicators of hydraulic performance, however the coefficient of variation of the flow is an indicator that has been used in several studies with wastewater (Silva et al., 2013; Batista et al., 2016; Mesquita et al., 2016b).

According to the exposed, the objective of this study was to evaluate the variation of the coefficient of flow variation, as well as to identify the main biological agents that cause obstruction in dripping units operating with times of swine effluent and public water supply.

\section{Materials and Methods}

The experiment was performed at the Pilot-unity of treatment and localized application of swine residual water (UTARS) of the Federal University of Viçosa (UFV) in Minas Gerais State, Brazil (2046'11.25" S and 4251'44.96" O) from August 2nd to September 10th, 2006.

The experiment was settled in subdivided plots, being the main plots the times of swine effuent (ES) and public water supply (AAP) application (U1 - 1 h of EF plus 3h of AAP; U2 - 2h of
EF plus $2 h$ of AAP; U3 - 3h of EF plus $1 \mathrm{~h}$ of AAP, U4 - 4h of ES), being the secondary plots the drippers types ( $G 1$ - not self-compensating dripper of $2.0 \mathrm{~L}$ $\mathrm{h}^{-1}$; $\mathrm{G} 2$ - not self-compensating dripper of $1.7 \mathrm{~L} \mathrm{~h}^{-1}$; and $\mathrm{G} 3$ - self-compensating dripper of $3.6 \mathrm{~L} \mathrm{~h}^{-1}$ ) and in the tertiary plots the times of evaluations $(0,20,40,60,80,100,120,140$ and 160h) of the coefficient of flow variation (FCV) in a completely randomized design (CRD) with three repetitions.

For this, an experimental bench was settled, consisting of a public water supply reservoir with $5.6 \mathrm{~m}^{3}(1)$, a swine effluent reservoir with $7.0 \mathrm{~m}^{3}$ (2), two pump sets of $3 \mathrm{CV}$ each (3), one disc filter with apertures of $130 \downarrow \mathrm{m}$ (4A), one sieve with a screen with openings of $47 \downarrow \mathrm{m}(4 \mathrm{~B})$, a main line in $32 \mathrm{~mm}$ PVC (5), a branch line in $32 \mathrm{~mm}$ PVC (6), four pressure regulating valves of $105 \mathrm{kPa}$ (7), dripper units operating with effluent application times of swine effluent -ES and public water supply - AAP (U1 - 1h of EF plus 3h of AAP, U2 - $2 h$ of EF plus $2 h$ of AAP, U3 - 3h of EF plus $1 h$ of $A A P, U 4$ - 4h of ES) and 12 drip subunits equipped with emitters G1, G2 and G3, as shown in Figure 1. In each drip subunit were installed nine

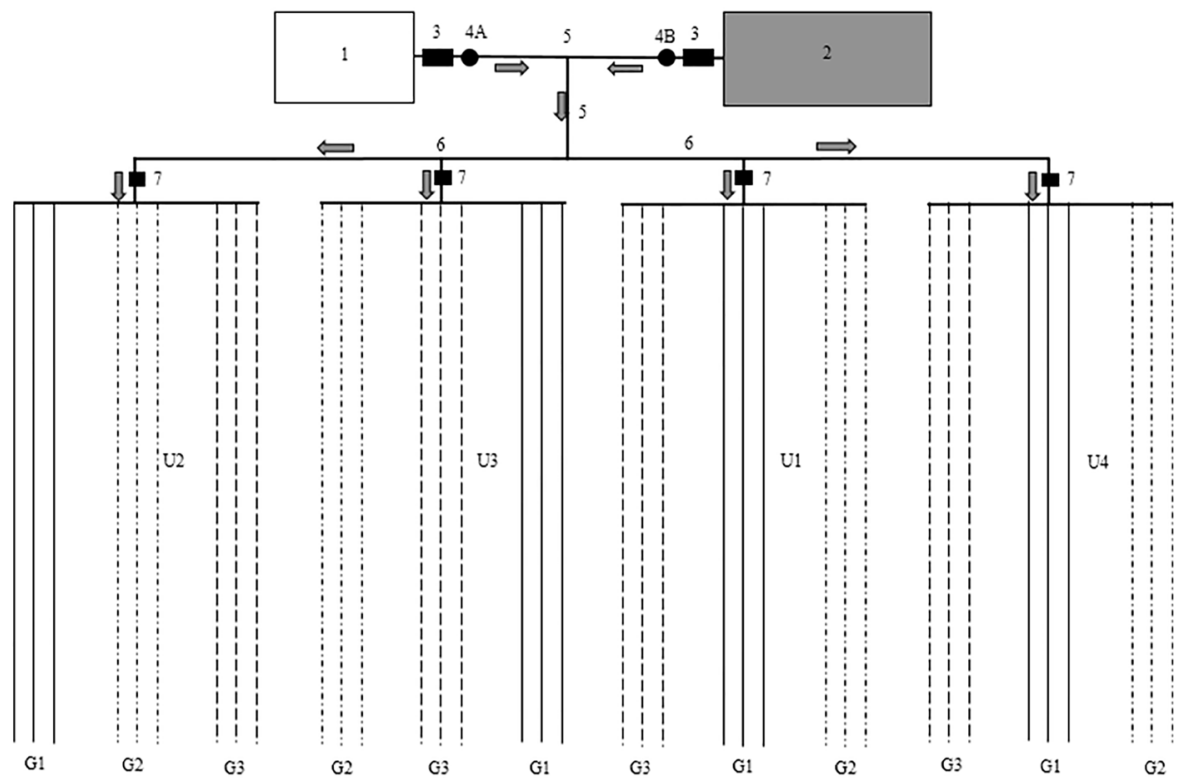

Source: U - Dripper units operating with times of application of swine effluent and public water supply; G1 - not selfcompensating dripper of $2.0 \mathrm{~L} \mathrm{~h}^{-1} ; \mathrm{G} 2$ - Not self-compensating dripper of $1.7 \mathrm{~L} \mathrm{~h}^{-1}$; and $\mathrm{G} 3$ - self-compensating dripper of $3.6 \mathrm{~L} \mathrm{~h}^{-1}$.

Figure 1. Scheme of dripper units and subunits, randomly drawn, operating with times of application of swine effluent and public water supply.

lateral lines in level, being three of each type of emitter with $18 \mathrm{~m}$ of length. The technical characteristics of the emitters tested with swine effluent application times and public water supply are shown in Table 1.
In these, 22 emitters were marked for flow measures, according to the collection of the applied volume during three minutes, according to the recommendations of NBR ISO 9261 (ABNT, 2006) for tests with drippers. Then, each emitter 
Table 1. Technical specifications of the drippers used in the experiment with the respective images, adapted from Batista et al. (2013) and Batista et al. (2014).

\begin{tabular}{lccccc}
\hline \multicolumn{1}{c}{ Drippers } & \multicolumn{1}{c}{ Nominal flow } & Orifice area & Labirinty lenght & $\begin{array}{c}\text { Recommended } \\
\text { pressure range }\end{array}$ & Drippers images \\
\cline { 2 - 5 } & rate $\left(\mathrm{L} \mathrm{h}^{-1}\right)$ & $\left(\mathrm{mm}^{2}\right)$ & $(\mathrm{mm})$ & $(\mathrm{kPa})$ \\
\hline $\begin{array}{l}\text { G1 - Not self- } \\
\text { compensating dripper }\end{array}$ & 2.00 & 4.45 & 327 & $80-300$ \\
$\begin{array}{l}\text { G2 - Not self- } \\
\text { compensating dripper }\end{array}$ & 1.70 & 1.86 & 176 & $40-100$ \\
$\begin{array}{l}\text { G3 - Self- } \\
\text { compensating dripper }\end{array}$ & 3.60 & 2.54 & 44 & $80-350$ \\
\hline
\end{tabular}

flow (qi in $\mathrm{L} \mathrm{h}^{-1}$ ) were calculated using the following equation (1):

$$
q_{i}=\frac{v}{1000 t} \quad 60
$$

In which:

$\checkmark$ - Volume of each effluent collected in each emitter, in $\mathrm{mL}$; and

t - time of effluent collection for each emitter, in minutes

With the emitters flow it was determined the coefficient of flow variation (FVC in \%) of the drippers subunits, using the equation 2 of NBR ISO 9261 (ABNT, 2006), for each 20 hours of operations until 160 hours, according to Silva et al., (2013), who detected levels of obstruction in drippers units that use waste water from cashew nuts at the same time of evaluation.

$$
F V C=100 \quad \frac{S D_{q}}{\bar{q}}
$$

In wich:

SDq - Standard deviation of the emitters flow for each dripper unit, in $\mathrm{L} \mathrm{h}^{-1}$; and

- Mean flow for the emitters in each dripper unit, in $\mathrm{L} \mathrm{h}^{-1}$.

The FVC values were classified according to ASAE EP 405 (Asabe, 2003), where the following values are suggested: less than 10\%, good (G); between 10 and $20 \%$, regular (R); and more than $20 \%$, unacceptable (U).

In Table 2 is possible to observe the mean value and the standard deviation of the physicalchemical characteristics of the swine effluent (ES) and the public supply water (AAP) applied by the dripper subunits.

Table 2. Mean and standard deviation for the physical-chemical characteristics of swine effluent (ES) and public

\begin{tabular}{|c|c|c|c|c|c|c|c|}
\hline \multirow[t]{2}{*}{ Fluids } & Temperature & $\mathrm{DBO}_{5}{ }^{20}$ & DQO & OG & Alc & $\mathrm{Na}^{+}$ & RAS \\
\hline & ${ }^{\circ} \mathrm{C}$ & $\mathrm{mg} \mathrm{L}^{-1}$ & \multicolumn{2}{|c|}{$\mathrm{mmol}_{\mathrm{c}} \mathrm{L}^{-1}$} & \multicolumn{3}{|c|}{$(\mathrm{mmolc} L-1)^{0.5}$} \\
\hline ES & $19.02 \pm 0.66$ & $602 \pm 252$ & $1228 \pm 635$ & $27 \pm 25$ & $1752 \pm 99$ & $2.14 \pm 0.20$ & $1.10 \pm 0.13$ \\
\hline AAP & $19.28 \pm 0.48$ & NR & NR & NR & NR & $0.34 \pm 0.10$ & $0.56 \pm 0.15$ \\
\hline
\end{tabular}
water supply (PSA) applied by dripper subunits. NR - Not realized.

During the experimental period, ES samples were collected on every $20 \mathrm{~h}$ of operation of the drip subunits, which were then preserved in an isothermal box at $4^{\circ} \mathrm{C}$ and sent to the laboratories of the Departments of Animal Biology and Plant Biology of the Federal University of Viçosa (UFV). In these samples the presence of fungi, protozoa, cyanobacteria, zooplankton and phytoplankton were identified, as well as their frequency of occurrence, through the microscopic examination of the collected samples.

After $160 \mathrm{~h}$ of operation of the drip subunits, samples of the material that caused the emitters obstructions were collected and immediately conditioned in a sterilized container, being preserved in an isothermal box at $4^{\circ} \mathrm{C}$, until the arrival at the laboratories of the Departments of Plant Biology, Animal Biology and Microbiology of the UFV and the Laboratory of Biological Processes of the Department of Hydraulics and Sanitation of USP, aiming to identify the agents 
that cause microscopic clogging using objective of 100 , ocular of 10 and zoom of 1.25.

\section{Results and Discussion}

According to the variance analysis, the interaction $N \times G \times T$ was significant at $1 \%$ of probability for the variable FCV, with $\mathrm{CV}$ of the tertiary plots of $32 \%$. Similar results were observed by Silva et al. (2013) studying dripping unities using cashew nuts production wastewater, with CV of $29 \%$ (Table 3 ).

Table 3. Variance analysis for the FCV variable, in a scheme of subdivided plots.

\begin{tabular}{lcc}
\hline Source of variation & Degree of freedom liberdade & Mean square \\
\hline Times of effluent and water application & 3 & $4266^{* *}$ \\
Residue (a) & 8 & 81 \\
Dripper type (G) & 2 & $1357^{* *}$ \\
$N \times G$ & 6 & $854^{* *}$ \\
Residue (b) & 16 & 53 \\
Time of operation (T) & 8 & $5416^{* *}$ \\
$N \times T$ & 24 & $762^{* *}$ \\
$G \times T$ & 16 & $253^{* *}$ \\
$N \times G \times T$ & 48 & $143^{* *}$ \\
Residue (c) & 192 & 18 \\
\hline CV (\%) main plots & & 68 \\
CV (\%) secondary plots & & 58 \\
$C V(\%)$ tertiary plots & & 32 \\
${ }^{* *}$ s significant at $1 \%$ of probability. CV - Coefficient of variation. & &
\end{tabular}

In Table 4, the mean values of FCV for the drip type factor were presented within each operating time level and each level of application time of swine effluent and public water supply. It was verified, in this table, that there was no effect of the effluent and water application times on the FCV, for each type of dripper, up to the operating time of $60 \mathrm{~h}$; this result differs from that obtained by Mesquita et al. (2016b) that showed a significant reduction of FCV, from $40 \mathrm{~h}$ of application of percolate of diluted landfill, in the dripper unit with a noncompensating emitter of $1.65 \mathrm{~L} \mathrm{~h}^{-1}$.

Using the classification of ASAE EP 405 (Asabe, 2003), it was shown that the value of FCV was classified as good ( $<10 \%)$ throughout the experimental period only in the drip subunits equipped with emitters $G 2$ and $G 3$ of $U 1$ and in the dripping subunits $G 1$ and $G 3$ of $U 4$, evidencing that the susceptibility to clogging is related to the constructive characteristics of the emitters and the quality of the applied fluid; however, at 160 h, the drip subunits $G 1, G 2$ and $G 3$ presented FCV classified as unacceptable (> 20\%) for U2 and $\mathrm{U} 3$, where the constructive characteristics of the emitters and the quality of the applied fluids contributed to obstruction of the emitters. It was also noted in Table 4 that the emitter obstruction started at 80 h in the $\mathrm{G} 4$ drip subunit of $\mathrm{U} 4$, where FCV was classified as regular ( $10 \%<\mathrm{FCV}<20 \%$ ).

These results are in accordance with those found by Mesquita et al. (2016b) in dripping units by applying percolated landfill diluted for $160 \mathrm{~h}$, where the not self-compensating dripper of $1.65 \mathrm{~L} \mathrm{~h}^{-1}$ resulted in FCV also classified as unacceptable, due drippers obstruction.

Comparing the means of the FCV variable followed by at least one same capital letter in the columns of Table 4, it was found that: at UI level, from $120 \mathrm{~h}$, the FCV of the subunit with G1 dripper differed from the FCV of the subunits with $G 2$ and $G 3$ drippers; at the U1 level, from 100 $h$, the FCV of the $G 1$ drip subunit differed from the FCV of the subunits with $G 2$ and $G 3$ drippers; at U3 level, the FCV of the G1 drip subunit differed from the FCV of the subunits equipped with the $\mathrm{G} 2$ and $\mathrm{G} 3$ drippers, at the 80,100 and $120 \mathrm{~h}$ operating times, while the FCV values of the $\mathrm{G}$, $G 2$ and $G 3$ drip subunits differed between them, in the operating times of 140 and $160 \mathrm{~h}$; and at U4 level, from $100 \mathrm{~h}$, the FCV of the subunits with G1 and G3 drippers differed from the FCV of 
Table 4. Mean values for FCV (\%) for the factor dripper type for each level of time of application of the effluent and water, with the respective ASAE EP 405 classification (Asabe, 2003).

\begin{tabular}{|c|c|c|c|c|c|}
\hline \multirow{2}{*}{$\begin{array}{c}\text { Operation time } \\
\text { (h) }\end{array}$} & \multirow{2}{*}{ Drippers } & \multicolumn{4}{|c|}{ Times of application of swine effluent and water from public supply * } \\
\hline & & U1 & U2 & U3 & U4 \\
\hline \multirow{3}{*}{ 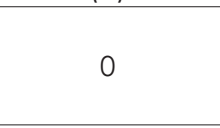 } & G1 & 2.37Aa (G) & $2.24 \mathrm{Aa}(\mathrm{G})$ & $2.04 \mathrm{Aa}(\mathrm{G})$ & $2.03 \mathrm{Aa}(\mathrm{G})$ \\
\hline & G2 & $1.78 \mathrm{Aa}(\mathrm{G})$ & $1.55 \mathrm{Aa}(\mathrm{G})$ & $1.59 \mathrm{Aa}(\mathrm{G})$ & $1.45 \mathrm{Aa}(\mathrm{G})$ \\
\hline & G3 & 2.85Aa (G) & 3.45Aa (G) & 3.47Aa (G) & 4.48Aa (G) \\
\hline \multirow{3}{*}{20} & G1 & $2.12 \mathrm{Aa}(\mathrm{G})$ & 1.94Aa (G) & $2.24 \mathrm{Aa}(\mathrm{G})$ & $2.62 A a(G)$ \\
\hline & G2 & $1.58 \mathrm{Aa}(\mathrm{G})$ & $1.68 \mathrm{Aa}(\mathrm{G})$ & $1.70 \mathrm{Aa}(\mathrm{G})$ & 1.49Aa (G) \\
\hline & G3 & 4.08Aa (G) & 3.89Aa (G) & 3.97Aa (G) & 4.30Aa (G) \\
\hline \multirow{3}{*}{40} & G1 & $2.18 \mathrm{Aa}(\mathrm{G})$ & 2.47Aa (G) & $3.54 \mathrm{Aa}(\mathrm{G})$ & 7.93Aa (G) \\
\hline & G2 & $2.08 \mathrm{Aa}(\mathrm{G})$ & $2.55 \mathrm{Aa}(\mathrm{G})$ & $2.47 \mathrm{Aa}(\mathrm{G})$ & 5.38Aa (G) \\
\hline & G3 & 3.47Aa (G) & 4.54Aa (G) & 6.27Aa (G) & $3.41 \mathrm{Aa}(\mathrm{G})$ \\
\hline \multirow{3}{*}{60} & G1 & 2.92Aa (G) & 3.35Aa (G) & 4.47Aa (G) & 5.35Aa (G) \\
\hline & G2 & $1.93 \mathrm{Aa} \mathrm{(G)}$ & $2.29 \mathrm{Aa}(\mathrm{G})$ & $2.21 \mathrm{Aa}(\mathrm{G})$ & $3.61 \mathrm{Aa}(\mathrm{G})$ \\
\hline & G3 & 4.11Aa (G) & 4.64Aa (G) & 6.18Aa (G) & $4.88 \mathrm{Aa}(\mathrm{G})$ \\
\hline \multirow{3}{*}{80} & G1 & 3.64Ab (G) & 8.82Ab (G) & $22.55 \mathrm{Aa}(\mathrm{U})$ & $4.36 \mathrm{Ab}(\mathrm{G})$ \\
\hline & G2 & $2.17 A a(G)$ & 5.86Aa (G) & $5.75 \mathrm{Ba}(\mathrm{G})$ & $12.29 \mathrm{Aa}(\mathrm{R})$ \\
\hline & G3 & 5.77Aa (G) & 6.82Aa (G) & $9.44 \mathrm{Ba}(\mathrm{G})$ & $3.75 \mathrm{Aa}(\mathrm{G})$ \\
\hline \multirow{3}{*}{100} & G1 & 9.37Ab (G) & 26.67Aa (U) & 30.73Aa (U) & $5.75 \mathrm{Bb}(\mathrm{G})$ \\
\hline & G2 & 3.26Ab (G) & 13.90Ba (R) & $17.21 \mathrm{Ba}(\mathrm{R})$ & 16.62Aa (R) \\
\hline & G3 & $4.81 \mathrm{Ab}(\mathrm{G})$ & 10.09Bab (R) (R) & $15.11 \mathrm{Ba}(\mathrm{R})$ & 5.00Bab (G) \\
\hline \multirow{3}{*}{120} & G1 & 17.46Ab (R) & $55.40 \mathrm{Aa}(\mathrm{U})$ & 47.78Aa (U) & $3.87 B C(G)$ \\
\hline & G2 & $4.38 \mathrm{BC}(\mathrm{G})$ & 25.93Bb (U) & $26.94 \mathrm{Bb}(\mathrm{U})$ & $37.20 \mathrm{Aa}(\mathrm{U})$ \\
\hline & G3 & $6.70 \mathrm{Bb}(\mathrm{G})$ & $27.82 \mathrm{Ba}(\mathrm{U})$ & 28.06Ba (U) & $3.73 \mathrm{Bb}(\mathrm{G})$ \\
\hline \multirow{3}{*}{140} & G1 & $20.47 \mathrm{Ab}(\mathrm{U})$ & 69.32Aa (U) & 62.75Aa (U) & $5.14 \mathrm{BC}(\mathrm{G})$ \\
\hline & G2 & $5.64 \mathrm{BC}(\mathrm{G})$ & $32.80 \mathrm{Bb}(\mathrm{U})$ & $43.13 \mathrm{Ba}(\mathrm{U})$ & $29.26 \mathrm{Ab}(\mathrm{U})$ \\
\hline & G3 & $5.58 \mathrm{Bb}(\mathrm{G})$ & 38.32Ba (U) & $32.40 \mathrm{Ca}(\mathrm{U})$ & $3.79 \mathrm{Bb}(\mathrm{G})$ \\
\hline \multirow{3}{*}{160} & G1 & $22.45 \mathrm{Ab}(\mathrm{U})$ & 77.71Aa (U) & 67.67Aa (U) & $7.17 \mathrm{BC}(\mathrm{G})$ \\
\hline & G2 & $7.94 \mathrm{BC}(\mathrm{G})$ & 37.46Bb (U) & 50.65Ba (U) & $35.61 \mathrm{Ab}(\mathrm{U})$ \\
\hline & G3 & $6.82 \mathrm{Bb}(\mathrm{G})$ & $45.11 \mathrm{Ba}(\mathrm{U})$ & $37.42 \mathrm{Ca}(\mathrm{U})$ & $4.43 \mathrm{Bb}(\mathrm{G})$ \\
\hline
\end{tabular}

the subunit provided with drip G2. These results differ from those presented by Silva et al. (2013), where the average FCV values of the dripper unit with non self-compensating emitter differs from the FCV of the other dripper units with selfcompensating emitters, after $20 \mathrm{~h}$ operation with cashew nut residual water under the service pressure of $70 \mathrm{kPa}$.

Comparing the means of the FCV variable followed by at least one same lowercase letter in the lines of Table 4, it was observed that: at the $80 \mathrm{~h}$ time, the FCV of the Gl subunit submitted to the Ul level differed from the FCV of the subunits submitted at levels U1, U2 and U4; in the operating time of $100 \mathrm{~h}$, the FCV of the subunits equipped with the $G 1$ drippers submitted to the UI and U4 levels differed from the FCV of the subunits submitted to levels U2 and U3, the FCV of the subunits with drip G2, submitted to the U1 level, differed of FCV of the subunits submitted to levels U2, U3 and U4, and the FCV of the subunits with $\mathrm{G} 3$ dripper, submitted to level U1, differed from the FCV of the subunit submitted to level U3; in the operating times of 120, 140 and $160 \mathrm{~h}$, the FCV values of the subunits equipped with the G1 and G2 drippers, submitted to levels U1, U3 and $U 4$, were different, while the FCV of subunits with G3 dripper, submitted to levels U1 and U4, differed from the FCV of subunits submitted to levels U2 and U3.

In Table 5, the biological groups present in swine wastewater are shown, according to the time of operation of the drip subunits, identified by optical microscopy.

The effluent of the phytoplancton was represented by the groups Bacillariophyta, Chlorophyta, Euglenophyta, Cyanophyta, Cryptophyta and Dinophyta. In the primary domestic wastewater, Batist et al. (2015) observed other groups of phytoplancton, such as Chlorella, Scenedesmus, Chaetophora and Navicula. The group Bacillariophyta was observed for all times of evaluation, bein mainly represented by Diatomaceous. The groups Chlorophyta and 
Table 5. Characterization of the biological groups presented in swine wastewater according to the operation periods of the drip units identified using the optical microscopy.

\begin{tabular}{|c|c|c|c|c|c|c|c|c|c|}
\hline \multirow{2}{*}{ Groups } & \multicolumn{9}{|c|}{ Observed frequencies for the operation periods (h) } \\
\hline & 0 & 20 & 40 & 60 & 80 & 100 & 120 & 140 & 160 \\
\hline \multicolumn{10}{|c|}{ Fitoplancton } \\
\hline Bacillariophyta & ++ & ++++ & ++++ & ++++ & ++++ & +++ & ++++ & +++ & +++ \\
\hline Chlorophyta & ++++ & - & ++ & +++ & +++ & +++ & +++ & +++ & ++++ \\
\hline Euglenophyta & +++ & +++ & +++ & ++ & +++ & ++++ & - & ++++ & +++ \\
\hline Cyanophyta & - & - & +++ & - & ++ & ++ & - & - & - \\
\hline Cryptophyta & - & ++ & - & +++ & - & - & - & - & - \\
\hline Dinophyta & - & - & +++ & - & - & - & - & - & - \\
\hline \multicolumn{10}{|c|}{ Zooplancton } \\
\hline Rotífera & - & - & - & - & - & - & - & - & - \\
\hline Cladocera & - & - & - & - & - & - & - & - & - \\
\hline Copepoda & - & - & - & - & - & - & - & - & - \\
\hline Bacteria & ++++ & ++++ & ++++ & ++++ & ++++ & ++++ & ++++ & ++++ & ++++ \\
\hline Fungi & +++ & +++ & +++ & +++ & +++ & +++ & +++ & +++ & +++ \\
\hline Protozoa & +++ & +++ & +++ & +++ & +++ & +++ & +++ & +++ & +++ \\
\hline
\end{tabular}

Euglenophyta were not observed, except for the periods of 20 and $120 \mathrm{~h}$, respectively. The group Cyanophyta was observed in the periods of 40,80 and $100 \mathrm{~h}$, being mainly represented by Cyanobacterias. The group Cryptophyta was observed in the periods of 20 e 60 h, while the Dinophyta group was only observed for the period of $40 \mathrm{~h}$. The lack of dissolved oxygen in the effluent avoided the developent of zooplancton groups such as Rotífera, Cladocera and Copepoda, commonly observed in secondary domestic effluents.

The biological groups bacteria, fungus and protozoa were also identified in the effluent throughout the testing period. In the study developed by Şahin et al. (2005), it was observed problems of drippers clogging due to the formation of mucilage by the activity of bacteria, fungi and protozoa.

Microscopic analysis of biofilms, performed to characterize the biomass present in each subunit (Figure 2), presented different phase contrast morphologies. In all biofilms, the predominant microorganisms were curved bacilli (probably sulphatereducing bacteria). bacilli in pairs, bacillus cocci, filaments, filamentous bacteria (similar to Methanosaeta) and diatoms. Moraes \& Paula Júnior (2004), studying swine effluent, found the predominance of curved bacilli, straight bacilli and cocci bacilli in the biofilm formed inside reactors. Luiz (2007) identified bacilli, bacillus cocci, filaments and bacteria similar to Methanosaeta and Methanosarcina in the biofilm formed in reactors operating with coffee production wastewater.

Evaluating the culture media, it was observed population level of bacteria that could cause drippers clogging, as shown in Table 6. The population levels of bacteria in the U1, U2, U3 and U4 biofilms were $8.5 \times 105,1.8 \times 106,1.9 \times 106$ and $1.1 \times 106 \mathrm{CFU} \mathrm{ml} \mathrm{m}^{-1}$, respectively. According to reports by Nakayama et al. (2006), the genera Enterobacter, Pseudomonas and Clostridium bacteria can cause serious obstruction problems in drippers.

Table 6. Characterization of the bacteria of the biofilm formed in the subunits submitted to the levels U1, U2, U3 and $\mathrm{U} 4$.

\begin{tabular}{lcccc}
\hline \multirow{2}{*}{ Bacteria } & \multicolumn{4}{c}{ Water proportion } \\
\cline { 2 - 5 } & $\mathrm{U} 1$ & $\mathrm{U} 2$ & $\mathrm{U} 3$ & $\mathrm{U} 4$ \\
\hline Bacteria population (UFC mL-1) & $8,5 \times 10^{5}$ & $1,8 \times 10^{6}$ & $1,9 \times 10^{6}$ & $1,1 \times 10^{6}$ \\
Enterobacter (UFC mL ${ }^{-1}$ ) & $2,0 \times 10^{3}$ & $7,5 \times 10^{3}$ & $4,5 \times 10^{3}$ & $2,0 \times 10^{3}$ \\
Pseudomonas (UFC mL ${ }^{-1}$ ) & $3,5 \times 10^{3}$ & $5,5 \times 10^{3}$ & $1,0 \times 10^{4}$ & $1,0 \times 10^{4}$ \\
${ }^{*}$ Clostridium (UFC $\mathrm{mL}^{-1}$ ) & $1,0 \times 10^{3}$ & $<10^{2}$ & $6,5 \times 10^{3}$ & $<10^{2}$ \\
\hline Note: UFC = colony forming units. ${ }^{*}$ Sulphite reducers Clostridium & & & &
\end{tabular}


A.

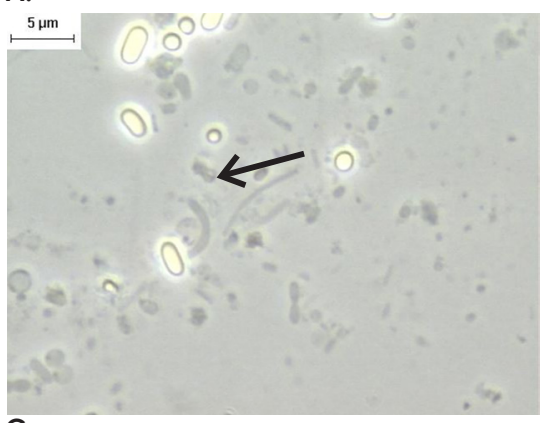

C.

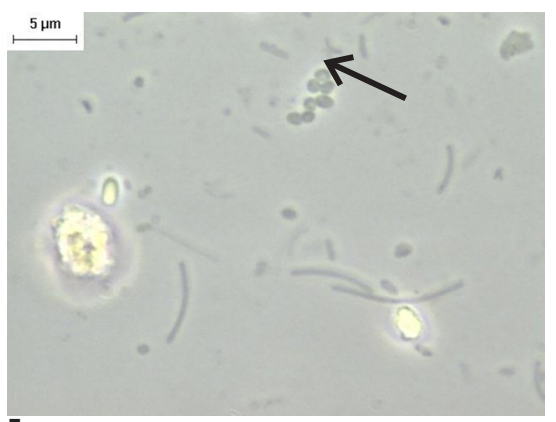

E.

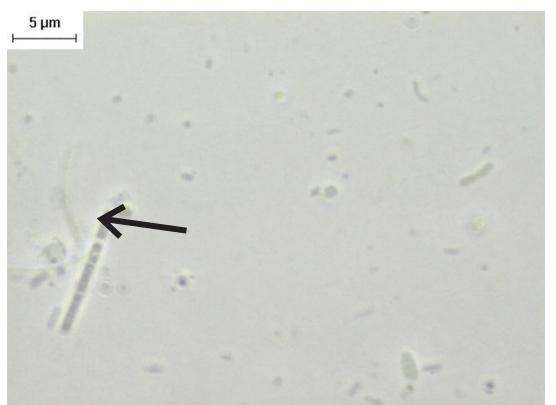

B.

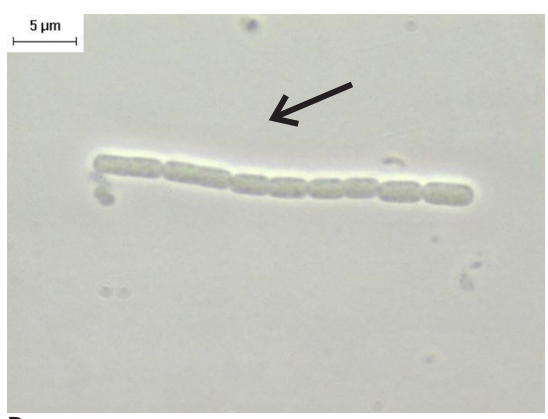

D.

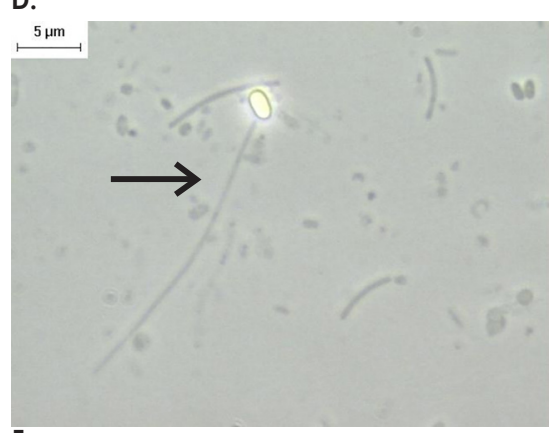

F.

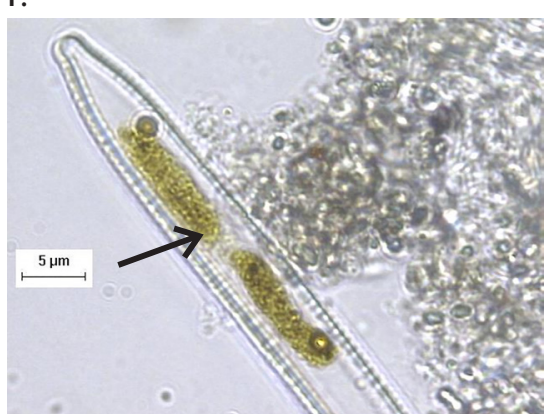

Figure 2. Morphologies observed by microscopy in the biofilm of subunit drippers submitfed to levels 1E3A, 2E2A, 3E1 A and 4E: bacillus curved (A), bacilli in pairs (B), cocci bacilli (C), filament (D), filamentous bacteria similar to Methanosaeta (E) and diatom (F) (objective of 100, ocular of 10 and zoom of 1.25).

\section{Conclusions}

The obstruction levels of the emitters were lower when the times of application of water of public supply were also lower.

The coefficient of variation of the flow was effective in detecting the clogging of the emitters, evidencing that the construction characteristics and the times of application of swine effluent and public water supply interfere in this process.

The main biological agents responsible for drip clogging were algae (Bacillariophyta, Chlorophyta, Euglenophyta, Cyanophyta, Cryptophyta and Dinophyta), bacteria (Enterobacter, Pseudomonas and Clostridium), fungi and protozoa.

\section{References}

ABNT. Associação brasileira de normas técnicas.
2006. Equipamentos de irrigação agrícola Emissores e tubos emissores - Especificações e métodos de ensaio. ABNT NBR ISO 9261. ABNT, São Paulo, Brasil. 17p.

Asabe. American society of agricultural and biological engineers. 2003. Design and installation of microirrigation systems. ASAE Standards EP 405, St. Joseph, p. 900-905.

Batista, R. O., Soares, A. A., Marin, O. L. Z., Souza, J. A. R., Sartori, M. A., Batista, R. O. 2009. Eficiencia del tratamiento químico en la prevención del taponamiento de goteros aplicando agua residual sanitaria tratada. Dyna 76: 149-157.

Batista, R. O., Oliveira, R. A., Santos, D. B., Oliveira, A. F. M., Azevedo, C. A. V., Medeiros, S. S. 2013. Obstrução e uniformidade de aplicação em sistemas de irrigação por gotejamento aplicando-se efluente da suinocultura. Revista Brasileira de Engenharia Agrícola e Ambiental 17: 698-705. 
Batista, R. O., Oliveira, R. A., Figueiredo, V. B., Silva, K. B., Ferreira, D. A. C. 2014. Vazão de gotejadores com distintos tempos de irrigação aplicando água residuária de suinocultura e água de abastecimento. Engenharia Agrícola 34: 1283-1295.

Batista, A. P., Ambrosano, L., Graça, S.; Sousa, C., Marques, P. A. S. S., Ribeiro, B.; Botrel, E. P., Castro Neto, P., Gouveia, L. 2015. Combining urban wastewater treatment with biohydrogen production - An integrated microalgae-based approach. Bioresource Technology 184: 230-235.

Batista, R. O., Oliveira, R. A., Santos, D. B., Cunha F. F., Medeiros, S. S. 2016. Modelos empíricos da aplicação de água residuária de suinocultura por gotejadores sob pressões de serviço. Irriga 21: 648-661.

Batista, R. O., Silva, K. B., Silva Júnior, M. J., Santos, D. B., Cunha, R. R. 2018. Performance of drip emitters for different pressures and application of cashew nuts wastewater. Dyna 85: 38-43.

Dazhuang, Y., Zhihui, B., Rowan, M., Likun, G., Shumei, R., Peiling, Y. 2009. Biofilm structure and its influence on clogging in drip irrigation emitters distributing reclaimed wastewater. Journal of Environmental Sciences 21: 834-841.

Eroglu, S., Sahin, U., Tunc, T., Sahin, F. 2012. Bacterial application increased the flow rate of $\mathrm{CaCO}_{3}$-clogged emitters of drip irrigation system. Journal of Environmental Management 98: 37-42.

Fernandes, R. K. A., Batista, R. O., Silva, S. K. C., Oliveira, J. F., Paiva, L. A. L. 2014. Vazão de gotejadores aplicando água residuária da castanha de caju. Irriga 19: 585-597.

Liu, H., Huang, G. 2009. Laboratory experiment on drip emitter clogging with fresh water and treated sewage effluent. Agricultural Water Management 96: 745-756.

Li, G., Li, Y., Xu, T., Liu, Y., Jin, H., Yang, P., Yan, D., Ren, S., Tian, Z. 2012. Effects of average velocity on the growth and surface topography of biofilms attached to the reclaimed wastewater drip irrigation system laterals. Irrigation Science 30: 103-113.

Luiz, F. A. R. 2007. Desempenho de reatores anaeróbios de leito fixo no tratamento de águas residuárias da lavagem e descascamento/ despolpa dos frutos do cafeeiro. $132 \mathrm{f}$. (Dissertação de Mestrado) - Universidade Federal de Viçosa, Viçosa, Brasil.

Marques, B. C. D., Cunha, V. T., Cunha, V. T., Silva, K. B., Batista, R. O. 2016. Desempenho de gotejadores operando com água residuária de laticínios em escala laboratorial. Irriga 21: 140155.
Mesquita, F. O., Alves, S. M. C., Batista, R. O., Dantas, T. B., Di Souza, L. 2016a. Desempenho de gotejadores aplicando percolado de aterro sanitário diluído. Irriga 21: 156-171.

Mesquita, F. O., Alves, S. M. C., Batista, R. O., Dantas, T. B., Di Souza, L. 2016b. Drip units operating with dilute landfill leachate. Revista Caatinga 29: 163-172.

Moraes, L. M., Paula Júnior, D. R. 2004. Avaliação da biodegrabilidade anaeróbia de resíduos da bovinocultura e da suinocultura. Engenharia Agrícola 24: 445-454.

Nakayama, F. S., Boman, B. J., Pitts, D. 2006. Maintenance. In: Lamm, F. R., Ayars, J. E., Nakayama, F. S. (eds.). Microirrigation for crop production: Design, Operation, and Management. Elsevier, Amsterdam, Holanda. cap. 11 , p. 389 - 430.

Oliver, M. M. H., Hewa, G. A., Pezzaniti, D. 2014. Biofouling of subsurface type drip emitters applying reclaimed water under medium soil thermal variation. Agricultural Water Management 133: 12-23.

Puig-Bargués, J., Arbat, G., Elbana, M., DuranRos, M., Barragán, J., Ramírez de Cartagena, F., Lamm, F. R. 2010. Effect of flushing frequency on emitter clogging in microirrigation with effluents. Agricultural Water Management 97: 883-891.

Şahin, Ü., Anapali, Ö., Dönmez, M. F., Şahin, F. 2005. Biological treatment of clogged emitters in a drip irrigation system. Journal of Environmental Management 76: 338-341.

Silva, K. B., Silva Júnior, M. J., Batista, R. O., Santos, D. B., Barbosa Filho, S. 2013. Desempenho de gotejadores operando com efluente da castanha de caju sob distintas pressões de serviço. Revista Ceres 60: 339-346.

Song, P., LI, Y., Zhou, B., Zhou, C., Zhang, Z., LI, J. 2017. Controlling mechanism of chlorination on emitter bio-clogging for drip irrigation using reclaimed water. Agricultural Water Management 184: 36-45.

Yan, D., Yang, P., Rowan, M., Ren, S., Pitts, D. 2010. Biofilm accumulation and structure in the flow path of drip emitters using reclaimed wastewater. Transactions of the ASABE 53: 751-758.

Zhou, B., Li, Y., Song, P., Xu, Z., Bralts, V. 2016. A kinetic model for biofilm growth inside non-PC emitters under reclaimed water drip irrigation. Agricultural Water Management 168: 23-34. 